\title{
De rol van (simulatie)patiënten in het onderwijs
}

\author{
S.L. Gorter, J.-J. Rethans, A.J.J.A. Scherpbier
}

\section{Samenvatting}

Patentencontacten motveren stidenten en leveren een bijage aan de vorming van betere kennisnetwerken, die nodig zin bij het omgaan met problemen van patienten. Patentendemonstrates en bedside teaching zin al langer toegepaste onderwis vomen. Van recenter datm zin de simulatepatenten, de als patent, docent examinator en onderzosker ingezet kunen worden. Ook echte patenten kunnen in verschillende rollen en onderwisvormen een bijage leveren aan het curriculum. De geschedenis en huidige stand van taken wan de rol van (simulatelpatenten in het onderwis passeren in dit artikel de rewe. Tot slot word betoogd dat een grotere rol van (simulatie/patenten op een wroeger tijatip in de opleiding de overgang van theorie nar prakble vergemakkelikt en het leren van de stident ten goede komt.

\section{Inleiding}

Studenten geneeskunde komen tijdens hun stages in aanraking met patiënten en de praktijk. Het belang van praktijk- en patiëntencontacten voor het leren van de student is altijd al erkend. Onlangs heeft de visitatiecommissie die in 1997 de faculteiten geneeskunde in ons land bezocht, het belang van deze contacten vroeg in het curriculum, opgenomen in haar aanbevelingen. ${ }^{1}$ Inmiddels wordt het belang van praktijkcontacten ook onderbouwd door onderzoeksresultaten uit de cognitieve psychologie. ${ }^{2}$ Uit dit onderzoek blijkt dat experts - in de geneeskunde zijn dat ervaren artsen - bij het oplossen van patiëntenproblemen gebruik maken van kennis die vooral gelieerd is aan eerdere ervaringen met patiënten en hun problemen. Door deze ervaringen bouwt de expert in zijn geheugen een 'galerij' van problemen op, bestaand uit een geheel van concepten en ervaringen die met elkaar verbonden zijn en als het ware een netwerk vormen. Bij elk contact met een nieuwe patiënt wordt deze patiënt - of liever diens probleem - cognitief gerelateerd aan een van de problemen uit de galerij: 'past dit probleem bij iets dat ik al eerder oploste?' De ervaren arts onderscheidt zich van studenten of pas afgestudeerden door beter functionerende kennisnetwerken, waardoor de arts sneller iets kan terugvinden in het geheugen dan de nieuweling. 3 Voor het opslaan en terugvinden van informatie blijken gegevens over de context - de situatie waarin informatie wordt opgeslagen - belangrijk te zijn. Als iets geleerd is in een laboratoriumsituatie die heel anders is dan de praktijksituatie, is het geleerde moeilijk terug te vinden op het moment dat het in de praktijk nodig is. De onderzoeksresultaten uit de cognitieve psychologie pleiten tegen de gedachte dat probleemoplossen als geïsoleerde vaardigheid bestaat. Ook uit onderzoek naar toetsing is gebleken dat probleemoplossen geen generieke vaardigheid is. ${ }^{4}$

Voor de opbouw van een goed kennisnetwerk is het van belang dat nieuwe informatie goed aansluit bij wat eerder geleerd is en dat er met véél problemen in véél verschillende - zo realistisch mogelijke - situaties geoefend wordt. Het vervroegen van patiën- 
tencontacten ligt dan ook voor de hand. Daarbij moet er wel rekening mee gehouden worden dat echte patiënten niet onnodig belast kunnen en mogen worden. Om dit te voorkomen en omdat echte patiënten niet altijd voor het onderwijs ingezet kunnen worden op momenten dat dat nodig is, zijn simulatie-situaties ontwikkeld.

In dit artikel wordt een kort overzicht gegeven van de historie van de simulatiepatiënt in het onderwijs, worden diverse in Nederland toegepaste onderwijsvormen met echte en simulatiepatiënten beschreven en zal tot slot worden ingegaan op de toekomst van de (simulatie)patiënt in het medisch onderwijs.

\section{Geschiedenis}

De erkenning dat studenten goed voorbereid moeten zijn op patiëntencontacten in de co-assistentschappen, heeft geleid tot de opkomst van het vaardigheidsonderwijs in de jaren zeventig en tachtig. Vaardigheidsonderwijs wordt nu aan alle medische faculteiten gegeven. ${ }^{5}$ Aangezien vaardigheidsonderwijs studenten moet voorbereiden op echte patiëntencontacten, wordt gebruik gemaakt van methoden die zo dicht mogelijk bij de echte praktijk liggen. Simulatiepatiënten, in de internationale literatuur vaak 'standardized patients' genoemd, zijn leken of echte patiënten (veelal met chronische aandoeningen) die getraind worden om een rol consistent en betrouwbaar te spelen. De neuroloog Barrows introduceerde in 1963 de eerste simulatiepatiënt als methode om de vaardigheid van co-assistenten in het klinisch redeneren, de anamnese en het lichamelijk onderzoek te verbeteren. 67 Deze 'geprogrammeerde' patiënt, die afwijkingen kon simuleren en feedback geven, bleek hiervoor prima geschikt te zijn. Na de eerste introductie duurde het echter nog vele jaren voordat de simulatiepatiënt als onderwijs- en toetsmethode algemeen geaccepteerd was. Het inzetten van simulatiepatiënten in het onderwijs aan medisch studenten vond in Nederland voor het eerst plaats in de faculteiten van Utrecht en Leiden. 89

Stillman was de eerste die zogenaamde 'patient-instructors' (mensen die als simulatiepatiënt ook echt doceren) introduceerde en Van Lunsen was de eerste die in Nederland simulatiepatiënten inzette als patiënt-docenten gynaecologisch onderzoek. 1011 Geleidelijk werd het duidelijker dat de veranderingen in het onderwijs ook moesten leiden tot veranderingen in de toetsing. Het toetsen van kennis via schriftelijke toetsvormen was een te beperkte methode om de competentie van studenten vast te stellen. Aan het eind van de jaren zeventig introduceerde Harden het stationsexamen (Objective Structured Clinical Examination (OSCE)), waarbij de vaardigheden van studenten geobserveerd werden. ${ }^{12} \mathrm{Bij}$ de evolutie van het OSCE werden steeds vaker simulatiepatiënten ingezet, aanvankelijk alleen voor de simulatie, later ook als beoordelaar.

\section{Welke rollen spelen patiënten en simulatiepatiënten?}

Patiëntendemonstraties en bedside teaching zijn van oudsher de bekendste onderwijsvormen waarbij patiënten een rol spelen. Patiënten en simulatiepatiënten kunnen in het medisch onderwijs in verschillende functies ingezet worden.

\section{Simulatiepatiënten als leermiddel}

Simulatiepatiënten worden in het gezondheidszorgonderwijs op vele plaatsen ingezet om de studenten in de gelegenheid te stellen te oefenen. De inhoud van het oefenen varieert van alleen communicatievaardigheden tot een volledig artspatiëntcontact. Ook het aantal oefenmogelijkheden voor studenten varieert. In het algemeen oefenen studenten aan het 
begin van de opleiding met simulatiepatiënten en echte patiënten met stabiele afwijkingen (dus in min of meer gecontroleerde onderwijssituaties), terwijl later in de opleiding meer contacten met echte patiënten in de (poli)kliniek plaatsvinden. De laatste jaren worden ook in vervolgopleidingen simulatiepatiënten ingezet.

Een speciale groep simulatiepatiënten zijn de lotuspatiënten (l.o.t.u.s. = landelijke opleiding tot uitbeelding van slachtoffers). Lotuspatiënten zijn in staat om ziekten en met name ongevalssituaties zeer realistisch uit te beelden. Vaak wordt daarbij gebruik gemaakt van visuele effecten zoals 'echt' bloed, uitstekende botten bij een breuk, et cetera. Aan de Universiteit Maastricht worden lotuspatiënten bijvoorbeeld ingezet in het blok 'Acute nood', waarin een ongevalssimulatie wordt georganiseerd in een brandweerkazerne. De studenten worden daarbij door docenten beoordeeld en krijgen direct feedback over hun handelen. ${ }^{13}$ In het verleden werden lotuspatiënten alleen ingezet bij het EHBO-onderwijs voor leken. Tegenwoordig werken zij mee aan rampensimulaties en oefeningen in bedrijven in het kader van de Arbo-wetgeving.

\section{Patiënten als leermiddel}

Studenten (en artsen) kunnen veel leren van echte patiënten. De patiënt is namelijk de enige deskundige op het gebied van zijn of haar eigen klachten en ervaringen. Mede daarom zijn contacten met echte patiënten onmisbaar in het medisch curriculum. Reeds lang bestaande onderwijsvormen waarbij van de specifieke kennis en ervaringen van patiënten gebruik gemaakt wordt, zoals patiëntendemonstraties en bedside teaching, lijken aan een revival te zijn begonnen. In het nieuwe medisch curriculum van de Faculteit der Medische Wetenschappen in Groningen wordt voor alle derdejaars studenten bedside teaching georganiseerd en vervullen patiëntende- monstraties een belangrijke functie in de eerste studiejaren. ${ }^{14} 15$ Aan de medische faculteit in Maastricht is in 1995 een start gemaakt met de zogenaamde klinische onderwijsgroepen in het vierde jaar van de opleiding. Hierbij bezoeken groepen studenten onder begeleiding van een docent (poli)klinische patiënten, waarbij ze leren een anamnese af te nemen en een differentiaaldiagnose op te stellen. Het doel van deze onderwijsmethode is integratie van theoretische en praktische kennis. ${ }^{16}$ In een aantal faculteiten maken de studenten in de eerste vier jaar van hun opleiding via korte stages in de huisartspraktijk kennis met patiëntenzorg. In het nieuwe curriculum in Groningen bijvoorbeeld vervolgt elke vierdejaars student twee patiënten vanaf de verwijzing door de huisarts tijdens de stage tot en met het bezoek aan de specialist. ${ }^{17}$

\section{(Simulatie)patiënten als docent}

In het onderwijs hebben simulatiepatiënten soms een rol als docent, zoals de simulatiepatiënten aan de medische faculteit in Nijmegen, die naast feedback over communicatievaardigheden ook inhoudelijke feedback over het medisch handelen geven.

Een speciale docentenrol van simulatiepatiënten is die bij het gynaecologisch en andrologisch onderzoek. Eind jaren zeventig werd door vrouwen geklaagd over de (gebrekkige) technische en emotionele vaardigheden van artsen bij het gynaecologisch onderzoek, terwijl ook studenten aangaven dat ze zich slecht voorbereid voelden op dit onderzoek. Van Lunsen ontwikkelde een onderwijsvorm waarbij gezonde vrouwen de studenten het gynaecologisch onderzoek aanleerden. Deze vrouwen hadden een dubbele rol: zij lieten zich onderzoeken en gaven onderwijs, zowel wat betreft de technische als de emotionele aspecten van het onderzoek. Inmiddels is deze onderwijsvorm, naast 
instructie en oefenen op fantomen, geaccepteerd voor zowel het gynaecologisch onderzoek als het onderzoek van de mannelijke genitalia in vrijwel alle faculteiten.

Een recente ontwikkeling is dat patiënten met stabiele afwijkingen optreden als docent voor huisartsen en studenten. Een voorbeeld hiervan is het Patient Partners Programma ${ }^{\circledR}$, waarbij studenten het onderzoek van gewrichten bij reumatische aandoeningen kunnen oefenen bij reumapatiënten die getraind zijn in het geven van dit vaardigheidsonderwijs. Ook vertellen deze patiënten over de beperkingen in hun dagelijks leven ten gevolge van hun reuma. Zij hebben een docerende rol in het leerproces en worden sinds 1998 in verschillende faculteiten ingezet in het onderwijs voor medisch studenten. 1819

Inmiddels worden ook verschillende patiëntenverenigingen ingezet bij het onderwijs aan medisch studenten in diverse faculteiten.

\section{Simulatiepatiënten als examinator}

Gestandaardiseerde patiënten met echte of gesimuleerde klachten blijken de competentie van studenten goed te kunnen beoordelen. ${ }^{2} 20$ Met name in het buitenland zijn goede ervaringen opgedaan met de rol van simulatiepatiënt-observatoren in toetssituaties.21-24 In Nederland wordt tot nu toe het beoordelen van studenten gezien als een rol voor een staflid. Een belangrijke voorwaarde voor het laten beoordelen door patiënten is dat deze in staat moeten zijn om tegelijkertijd én hun rol goed te spelen én de prestaties te beoordelen. Een zorgvuldige training is hiervoor noodzakelijk.

\section{Simulatiepatiënten als onderzoeker}

Begin jaren tachtig zijn simulatiepatiënten voor het eerst ingezet voor onderzoek. Huisartsen werden in hun eigen praktijk door gestandaardiseerde patiënten be- zocht. De huisartsen hadden hiervoor toestemming gegeven, maar wisten niet of en wanneer de simulatiepatiënten in hun praktijk zouden komen. De simulatiepatiënten registreerden aan de hand van checklisten het handelen van de huisarts. In een laboratoriumsituatie op het Skillslab in Maastricht werden vervolgens de consulten herhaald met dezelfde huisartsen en dezelfde rollen van simulatiepatiënten. Ook deze consulten werden aan de hand van de checklists gescoord. Er bleek verschil te bestaan tussen wat artsen doen in een laboratoriumsituatie (competence) en in de praktijk (performance). ${ }^{25}$ Veel van het onderzoek bij artsen met behulp van simulatiepatiënten is in de eerste lijn verricht. ${ }^{24-29}$ Momenteel loopt een onderzoek waarbij simulatiepatiënten incognito reumatologen in de tweede lijn bezoeken. 30 Deze simulatiepatiënten rapporteren zelf over het handelen van de specialist door na het bezoek een rolspecifieke checklijst in te vullen.

\section{De toekomst van de (simulatie)patiënt in het medisch onderwijs}

Het medisch curriculum in ons land is opgebouwd uit een vier jaar durende, hoofdzakelijk theoretische, fase en een praktische fase van ongeveer twee jaar, de co-assistentschappen. In de co-assistentschappen vinden veel praktijkcontacten plaats, dit in tegenstelling tot de eerste vier jaar van de opleiding. Een onderzoek onder medisch studenten in Maastricht laat zien dat studenten moeite hebben met de overgang naar de co-assistentschappen, ondanks het probleemgestuurd onderwijs aan deze faculteit en ondanks de regelmatige contacten met simulatiepatiënten tijdens de eerste vier jaar van de opleiding. 31 Een nieuw programma in Maastricht, de hierboven beschreven klinische onderwijsgroepen, biedt vierdejaars studenten de gelegenheid te oefenen in het afnemen 
van de anamnese en opstellen van de differentiaaldiagnose bij patiënten in de (poli)kliniek. Recent werd dit programma geëvalueerd met behulp van focusgroepinterviews. ${ }^{16}$ Uit de resultaten blijkt dat studenten deze onderwijsvorm zeer waarderen en dat het hen helpt het ziektebeeld en de kennis hierover te onthouden. De studenten pleiten dan ook voor regelmatige contacten met echte patiënten, ook vroeg in het curriculum. Naast deze onderwijsvorm noemen de studenten ook patiëntendemonstraties en bedside teaching. Eerdere onderzoeken over patiëntencontacten vroeg in het curriculum leverden vergelijkbare resultaten op. ${ }^{32-34}$ Patiënten blijken zelf enthousiast te zijn over hun rol in het onderwijs. 35

Omdat het doel van de medische opleiding is studenten zelfstandig patiëntenzorg te laten verrichten, is een situatie met een patiënt de ideale context voor het leren. Daarbij horen een goede begeleiding door en nabespreking met een docent, om deze ervaring een goede plaats te geven in het kennisnetwerk-in-ontwikkeling van de medisch student. Een bijkomend voordeel is dat studenten door praktijkcontacten gemotiveerd worden om te studeren. Deze patiënten- en praktijkcontacten zouden dan ook al vanaf het begin van het curriculum, onder goede begeleiding, moeten plaatsvinden, waarbij de context van dit contact steeds 'echter' en ingewikkelder wordt. De oorspronkelijke curriculumopbouw van vier jaar theorie en twee jaar praktijk lijkt dan ook aan verandering toe te zijn. De gekantelde $\mathrm{H}$ van deze opbouw zal veranderd moeten worden in een Z-vorm, waarbij vroeger in het curriculum met patiëntencontacten begonnen wordt en in de laatste twee jaar van de studie dieper op de theorie wordt ingegaan dan nu het geval is. ${ }^{36}$

Samenvattend, kunnen we zeggen dat (simulatie)patiënten een belangrijke rol spelen in de opleiding van medisch studenten. Voor het leren is het van belang om vroeg in het curriculum in contact te komen met de 'werkelijkheid' van patiënten, zowel gesimuleerd als echt. In de toekomst zal de rol van de patiënt dan ook groter worden. Er zal een verschuiving moeten optreden van 'papier' naar 'patiënt', waarbij het leren van de student centraal staat.

\section{Literatuur}

1. VSNU visitatiecommissie Geneeskunde en Gezondheidswetenschappen. Onderwijsvisitatie geneeskunde en gezondheidswetenschappen. Utrecht: Vereniging van Samenwerkende Nederlandse Universiteiten, 1997.

2. Schmidt HG, Norman GR, Boshuizen HP. A cognitive perspective on medical expertise: theory and implication. Acad Med 1990;65(10):611-21.

3. Regehr G, Norman GR. Issues in cognitive psychology: implications for professional education. Acad Med 1996;71(9):988-1001.

4. Vleuten CPM van der, Swanson DB. Assessment of clinical skills with standardized patients: state of the art. Teaching and Learning in Medicine 1990;2(2):58-76.

5. Metz JCM, Scherpbier AJJA. Systematische vaardigheidstraining als voorbereiding op de co-assistentschappen. Ned Tijdschr Geneeskd 1989;133: 561-4.

6. Barrows $\mathrm{SH}$, Abrahamson S. The programmed patient: a technique for appraising students' performance in clinical neurology. J Med Educ 1964;39:802-5.

7. Barrows SH. An overview of the uses of standardized patients for teaching and evaluating clinical skills. Acad Med 1993;68:443-51.

8. Roest F. Patiëntensimulatie in de verloskunde en in de gynaecologie. Medisch Contact 1976;31:265-7.

9. Oppelaar L, Gerritsma J. Geprogrammeerde patiënten in de kliniek voor inwendige geneeskunde. Medisch Contact 1976;31:261-4.

10. Stillman PL, Rugill JS, Rutala PJ, Sabers DL. Patient instructors as teachers and evaluators. J Med Educ 1980;55:186-93.

11. Lunsen HW van. Wie is er bang voor het gynaecologisch onderzoek? [proefschrift]. Groningen: Rijksuniversiteit Groningen; 1986.

12. Harden RM, Gleeson FA. Assessment of clinical competence using an objective structured clinical examination (OSCE). Med Educ 1979;13(1):41-54.

13. Vooijs MEEC, Scherpbier AJJA, Dalen J van, Ramsay G, Kootstra G. Group objective structured clinical examination in an inter-European 
accident and emergency course. Education for Health 1997;10(1):69-78.

14. Venekamp R, Thijs CP, Kolk MJ van der, Scherpbier AJJA. Bedside teaching chirurgie voor derdejaars studenten geneeskunde - satisfactie bij patiënten. In: Spaai GWG, Verweij AMJJ, Remmen R, Dolmans DHJM, Denekens JPM, Smal JA, Albersnagel EPL, Dikkers JH, redactie. Gezond Onderwijs-8; Proceedings Gezond Onderwijs Congres 1998. Houten/Diegem: Bohn Stafleu Van Loghum; 1999. p. 306-9.

15. Rossum HJM van, Bakker W. Patiëntendemonstraties. In: Metz JCM, Scherpbier AJJA, Vleuten CPM van der, redactie. Medisch onderwijs in de praktijk. Assen: Van Gorcum \& Comp. B.V.; 1995. p. 121-8.

16. Wiel MWJ van de, Schaper NC, Scherpbier AJJA, Vleuten CPM van der, Boshuizen HPA. Students' experiences with real patients tutorials in a problem-based curriculum. Teaching and Learning in Medicine 1999;11(1):12-20.

17. Reenders K. Transmuraal onderwijs in C2000: een evaluatie. In: Spaai GWG, Verweij AMJJ, Remmen R, Dolmans DHJM, Denekens JPM, Smal JA, Albersnagel EPL, Dikkers JH, redactie. Gezond Onderwijs-8; Proceedings Gezond Onderwijs Congres 1998. Houten/Diegem: Bohn Stafleu Van Loghum; 1999. p. 247-51.

18. Branch V, Neville-Smith M. Comparison of musculoskeletal examination skills of occupational therapy students with video demonstration and hands-on instruction. American College of Rheumatology 61st National Scientific Meeting and Association of Rheumatology Health Professionals 32nd National Scientific Meeting. Washington, DC, November 8-12, 1997. Abstracts. Arthritis Rheum 1997 Sep;40(9 Suppl):S239.

19. Branch V, Lipsky P. Comparisons of the perceived value by medical students of trained arthritis educators vs standardized patients, simulated patients and attending physicians in teaching the musculoskeletal examination. American College of Rheumatology 61st National Scientific Meeting and Association of Rheumatology Health Professionals 32nd National Scientific Meeting. Washington, DC, November 8-12, 1997. Abstracts. Arthritis Rheum. 1997 Sep;40(9 Suppl):S241.

20. Collins J, Harden RM. Real patients, simulated patients and simulators in clinical examinations. Med Teach 1988;20(6):508-21.

21. Vu NV, Marcy MM, Colliver JA, Verhulst SJ, Travis TA, Barrows HS. Standardized (simulated) patients' accuracy in recording clinical performance checklist items. Med Educ 1992;26(2):99-104.

22. Tamblyn RM, Klass DJ, Schnabl GK, Kopelow ML. Sources of unreliability and bias in standardized patient ratings. Teaching and Learning in Medicine 1991;3:74-85.
23. Vu NV, Barrows HS. Use of standardized patients in clinical assessment: recent developments and measurement findings. Educational Researcher 1993;23(3):23-30.

24. Rethans J-J, Drop R, Sturmans F, Leeuwen Y van. Simulatiepatiënten in onderwijs en praktijk. Een literatuuroverzicht. Huisarts en Wetenschap 1989;32:399-369.

25. Rethans JJ, Sturmans F, Drop R, Vleuten CPM van der, Hobus P. Does competence of general practitioners predict their performance? Comparison between examination setting and actual practice. Br Med J 1991;303:1377-80.

26. Rethans JJ, Boven CP van. Simulated patients in general practice: a different look at the consultation. Br Med J 1987;294:809-12.

27. Ramsey PG, Curtis JR, Paauw DS, Carline JD, Wenrich MD. History-taking and preventive medicine skills among primary care physicians: an assessment using standardized patients. Am J Med 1998;104(2):152-8.

28. Davis P, Russell AS, Skeith KJ. The use of standardized patients in the performance of a needs assessment and development of a CME intervention in rheumatology for primary care physicians. J Rheumatol 1997;24(10):1995-9.

29. Wenrich MD, Curtis JR, Carline JD, Paauw DS, Ramsey PG. HIV risk screening in the primary care setting. Assessment of physicians' skills. J Gen Int Med 1997;12:107-13.

30. Gorter SJ, Rethans J-J, Heijde D van de, et al. Preparing a standardized patient project in daily clinical practice of rheumatologists. The eighth international Ottawa conference on medical education and assessment. Philadelphia, USA, 1998, ter perse.

31. Prince K, Wiel van de M, Scherpbier A, Vleuten van der C, Boshuizen H. A qualitative analysis of the transition from theory to practice in medical education. Advances in Health Sciences Education. 1999, ter perse.

32. Briggs Style C, Maxwell JA, Moore GT. The effects of early patient contact: the student's perspective. Acad Med 1990;65(9 Suppl):S33-4.

33. Cade J. An evaluation of early patient contact for medical students. Med Educ 1993;27(3):205-10.

34. Johnson AK, Scott CS. Relationship between early clinical exposure and first-year students' attitudes toward medical education. Acad Med 1998;73(4):430-2.

35. Lynoe N, Sandlund M, Westberg K, Duchek M. Informed consent in clinical training-patient experiences and motives for participating. Med Educ 1998;32(5):465-71.

36. Scherpbier AJJA. Verwijnen GM, Schaper N, Dunselman GAJ, Vleuten CPM van der. Vaardigheidsonderwijs nu en in de toekomst. Tijdschrift voor Medisch Onderwijs 2000;19(1):6-15. 
De auteurs

S.L. Gorter is als arts-onderzoeker werkadam bj de Werkgroep Reumatologie van de vakgroep Interne Geneskunde, Academisch Ziekenhuis Mastricht.

Dr. J.J. Rethans, hisarts, is als coordinator medisch praktisch onderwijs verbonden aan het $5 k i l s l a b$ wan de Faculteit der Geneeskunde, Universiteit Mastricht. Frof. dr. AJJ.A Scherpbier is wetenschappelik direc- teur van het Onderwisinstitut van de Faculteit der Geneeskunde, Universiteit Mastricht.

Correspondentieadres:

5.L. Gorter, Werkgrop Reumatologie, Academisch Ziekenhuis Maastricht, Postbus 5800, 6202 AZ Maastricht, Tel: 043-3881429, E-mail: simone.gorter@intmedunimas.n?

\section{Summary}

Encounters with patents are motvating for students and contribute to the development of knowledge network that students need for the management of patient problems. Patent demonstrations and bedside teaching are traditional educational formats. More recenty simulated patents have contributed to stdent leaming as patents, teachers, examiners and researchers. Real patents can also contribute to the medical curriculum in a variety of roles and educational formats. An overview is presented of the educational roles of (simulated) patents. It is argued that a greater role for (simulated) patents from an earlier phase of the medical curriculum will facilitate the transition from theory to clinical practice and hence benefit student learning. (Gorter SL, Rethans J-J, Scherpbier AJA. The role of (simulated) patients in medical education. Dutch Joumal of Medical Education 2000; $19(2): 42-48)$ 